\title{
A Cloud-to-Ground Lightning Climatology for Romania
}

\author{
BOGDAN ANTONESCU AND SORIN BURCEA \\ National Meteorological Administration, Bucharest, Romania
}

(Manuscript received 20 February 2009, in final form 12 August 2009)

\begin{abstract}
The first study of the characteristics of cloud-to-ground (CG) lightning in Romania, based on the data recorded by the Romanian National Lightning Detection Network (RNLDN), is presented. The data, more than 1.75 million CG flashes, covers the entirety of Romania and were recorded between January 2003 and December 2005 and January and December 2007. The spatial analyses (total and positive flash density, the percentage of positive flashes, and negative and positive peak currents) were done with a resolution of $20 \mathrm{~km}$. The average spatial distribution shows a maximum (3.06 flashes $\mathrm{km}^{-2} \mathrm{yr}^{-1}$ ) over the south slopes of the central meridional Carpathians possibly associated with the Romanian Plain convergence zone. The mean monthly variation shows maximum CG lightning between May and September (98\%) and minimum values in December and January. High values $\left(>0.028 \mathrm{~km}^{-2} \mathrm{yr}^{-1}\right)$ for positive CG lightning density are observed in southwestern and central Romania. The monthly distribution of positive flashes shows a main maximum in May $(25 \%)$ and a secondary maximum in August (23\%), suggesting that positive flashes tend to occur earlier in the year than total flashes. The mean annual percentage of positive flashes has lower values at $1.3 \%$ in the central parts of the country. The percentage of positive CG flashes changes over the year from 1\% in June to $19 \%$ in January. The monthly variation of the median first-strike peak currents has a maximum in winter and reaches a minimum in July, for both negative and positive currents. The mean diurnal cycle for total CG lightning flashes peaks between 1230 and 1430 UTC (2.2\%) and shows a minimum between 0600 and 0800 UTC (0.3\%).
\end{abstract}

\section{Introduction}

Cloud-to-ground (CG) lightning is one of the leading causes of weather-related fatalities in the United States (Holle et al. 1999); only flash floods rank higher than lightning in terms of deaths (Curran et al. 2000). Information concerning the spatial and temporal distribution of CG lightning is critical, because major property damage, power system breakdowns, and forest fires are closely related to lightning flashes (Wierzchowski et al. 2002). Based on a dataset for the period 2003-07 provided by the Romanian National Institute of Statistics, we have been able to estimate the number of deaths related to CG lightning flashes in Romania (Fig. 1) at 336 victims, or an average of 56 deaths per year, representing the major cause of weather-related deaths in Romania. More deaths occur in rural areas than urban areas (Fig. 1).

Despite the interest in long-term characteristics of CG lightning activity, the number of studies is limited in

Corresponding author address: Bogdan Antonescu, Romanian National Meteorological Administration, sos. Bucuresti-Ploiesti 97, Bucharest 013686, Romania.

E-mail: bogdan.antonescu@meteoromania.ro
Europe compared to the United States. Most of the CG lightning climatologies are for the western and central part of Europe (e.g., Finke and Hauf 1996 for southern Germany; Schulz et al. 2005 for Austria; Rivas Soriano et al. 2005 for Iberian Peninsula; Tuomi and Mäkelä 2008 for Finland; Biron 2009 for Italy), and to our knowledge no published climatology exists for eastern Europe. This study is the first attempt to characterize the lightning climatology in Romania, situated in the extreme eastern Europe.

Rivas Soriano et al. (2005) have analyzed a 10 -yr period of CG lightning data (1992-2001), provided by the Spanish Lightning Detection Network (SLDN), and the results show that the CG lightning density is primarily related to topography and other factors, such as the general atmospheric circulation over the country or sea temperature. The maximum lightning activity is found at the Pyrenees and the Iberian Range, with the highest CG lightning density located along the Mediterranean Sea and especially along the coasts of Catalonia.

Using the data provided by the Austrian Lightning Detection and Information System (ALDIS), Schulz et al. (2005) have presented a CG lightning statistic for the period 1999-2001. Meteorological and topographical 


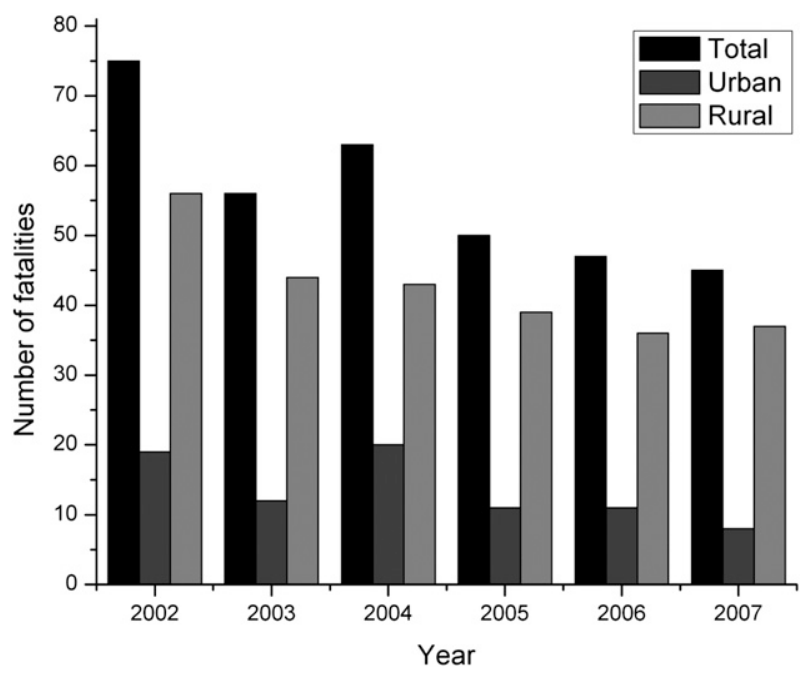

FIG. 1. Estimate of lightning-related fatalities in Romania for 2002-07, based on data gathered by the Romanian National Institute of Statistics.

conditions favor the south of Austria, close to the border of Italy and Slovenia, as the area with the highest CG lightning activity. The main Alpine crest is characterized by a pronounced minimum. Responsible for this feature are the glaciated areas because of their high albedo and the absence of an adequate moisture source in the inner Alpine dry area.

Finke and Hauf (1996) studied the temporal and spatial distribution of CG lightning in southern Germany between 1992 and 1994, using data from the Lightning Position and Tracking System (LPATS). The spatial distribution of CG lightning shows a preference for certain areas, such as the leeward side of the Black Forest and other parts of the Alpine foreland where the highest values of CG lightning density are observed.

Biron (2009) has shown that in Italy, the areas with highest values of CG lightning density are Lake Como, Gulf of Trieste, Liguria and the central Apennine, the Gulf of Naples, and inland Sardinia, based on the CG lightning recorded by the Italian National Met Service Lightning Network (LAMPINET) between 2005 and 2007.

Tuomi and Mäkelä (2008), using data provided by the Nordic Lightning Information System (NORDLIS), have identified the middle region of Finland as the region with the highest CG lightning density. Southern and southwestern coastal areas of Finland show low values of CG lightning density. Tuomi and Mäkelä (2008) also stated that except for the coastal zones, the general variation of CG lightning density "does not have an obvious correlation with the topography, which contains numerous small lake and low hills."
The first general study on climate and weather phenomena by seasons over a whole year was published in Romania in 1896. Since 1922, monthly bulletins have presented "normal" climatological data (multiyear means for the period 1896-1925), which also include the number of days with lightning per month and per year. Iliescu (1989) used the 1951-80 daily (audio visual) observations, performed at weather stations, and the 1966-80 observations, from CG lightning counters, to develop the first climatology of lightning in Romania. These data were not recorded continuously in a spatial or temporal sense, and the study just provided a general view of a lightning climatology. Once the RNLDN was implemented in 2002, building a CG lightning database with no time gaps and extending throughout contiguous Romania became possible.

The purpose of this study is to present the first climatology of the average annual spatial distribution, the average monthly distribution, and the diurnal variation of CG lightning flashes in Romania, based on data recorded by the RNLDN. The next sections of the paper are organized as follows: section 2 describes the dataset and the methodology used in this study, section 3 contains the results of the study, and section 4 presents the conclusions.

\section{Data from the RNLDN}

The Romanian National Lightning Detection Network was implemented in 2002 within the National Integrated Meteorological System (SIMIN, Romania) project (Ioana et al. 2004). Since August 2002, the Surveillance et Alerte Foudre par Interférométrie Radioélectrique (SAFIR3000) lightning detection network has been operating in Romania (Fig. 2). The system provides information on its own display, but the data are also integrated into the Romanian National Meteorological Administration (RNMA) data flow and can be displayed on other integrated platforms and applications. The RNLDN consists of eight SAFIR3000 total lightning automatic detection stations, with a network center situated at the RNMA headquarters in Bucharest, comprising a central processing system and main user terminal. The detection stations consist of a very high frequency (VHF) interferometric sensor designed to perform the accurate angular localization of thunderstorm electrical activity, both intracloud (IC) and CG lightning, complemented by a wide-band low-frequency (LF) electric field sensor for the characterization of lightning flashes to ground. The sensors have a detection efficiency estimated by the manufacturer at about $90 \%$. No correction for detection efficiency was made as we analyzed the measured values. The reasons are the RNLDN working parameters and detection accuracy was steady during the study period, 


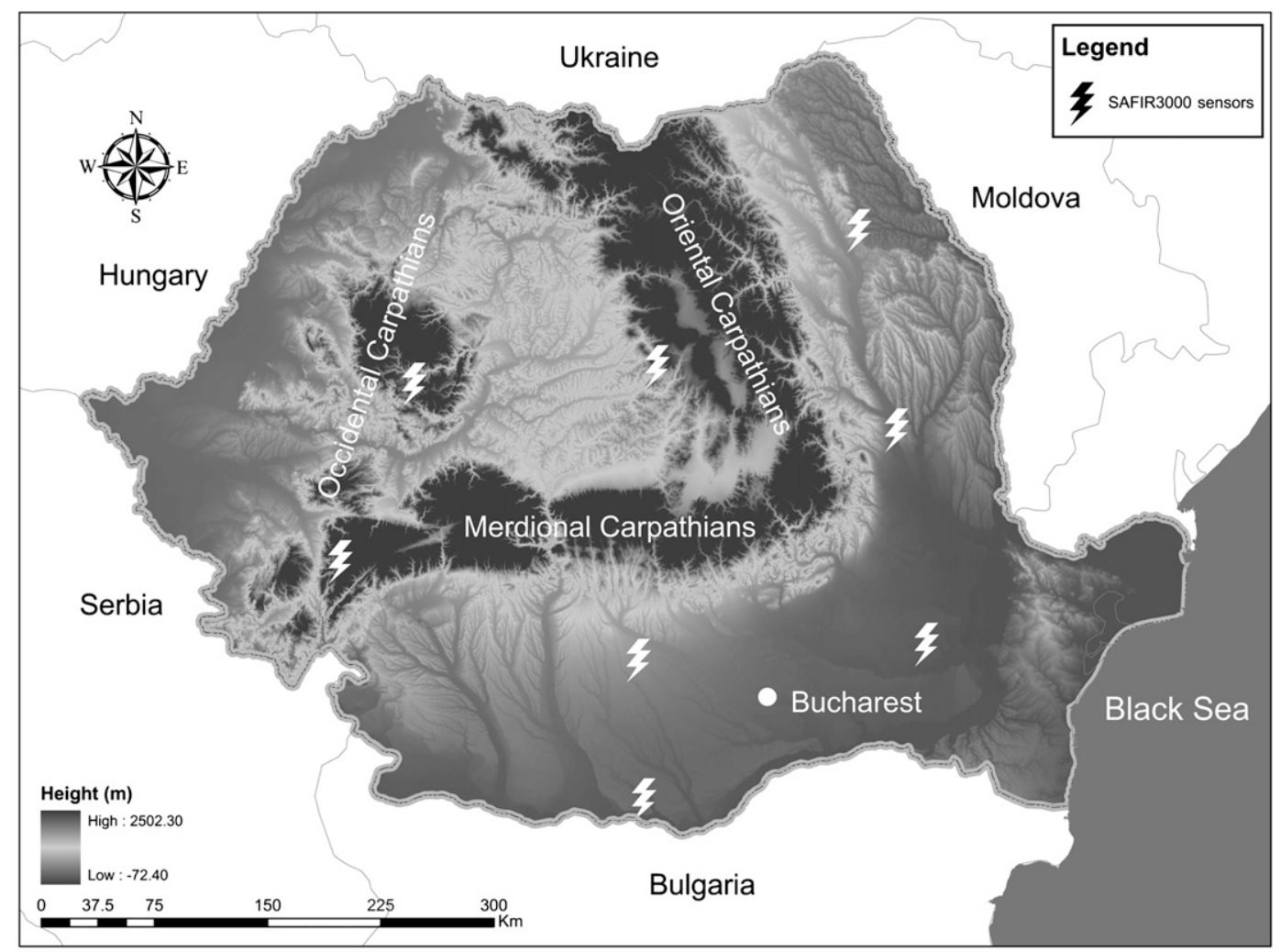

FIG. 2. Lightning sensor location of the NLDN and the topography of Romania.

except for 2006 when some of the detection stations malfunctioned. Outside the Romanian borders, the detection efficiency decreases, and the CG lightning distribution is a combination of the network performances and natural variations. The network provides national coverage to less than 1-km accuracy, for both IC and CG lightning. The CG lightning data cover the period between 2003 and 2007. As a result of the malfunctions of the RNLDN in 2006, the data corresponding to this year were only partially available and were excluded from the analysis. Also, all the positive CG lightning flashes with peak current less than $10 \mathrm{kA}$ were considered to be IC lightning (Cummins et al. 1998; Wacker and Orville 1999a,b) and have been removed. These procedures leave a total of approximately 1.75 million CG flashes.

The CG lightning dataset was available in American Standard for Information Exchange (ASCII) format. Information contained in the files includes the location and time (UTC) for each flash and the charge lowered by the CG lightning (either positive or negative). The ASCII files were analyzed using ArcGIS software to develop CG lightning density maps.

The density maps are based on dividing the study area into a grid with $20-\mathrm{km}$ cells. The grid used in previous studies (Zajac and Rutledge 2001; Orville and Huffines
2001 for the United States; Rivas Soriano et al. 2005 for Iberian Peninsula) was divided into $0.2^{\circ} \times 0.2^{\circ}$ cells. The $0.2^{\circ}$ (approximately $20 \mathrm{~km}$ ) grid was selected to correspond with the audible range of thunder (Reap and Orville 1990). ArcGIS software was used to calculate

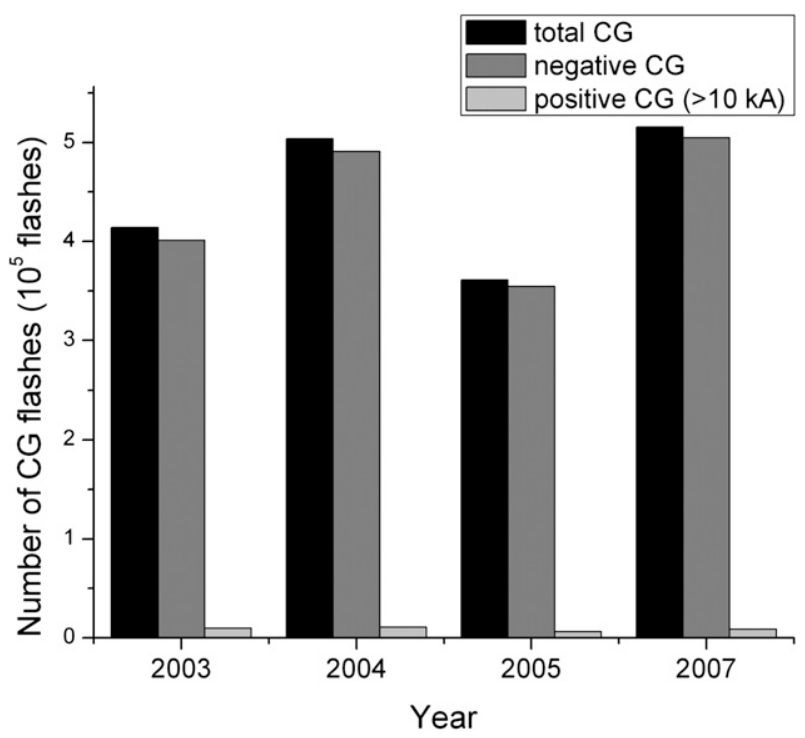

FIG. 3. Annual lightning flash counts from 2003 to 2007, except 2006. 


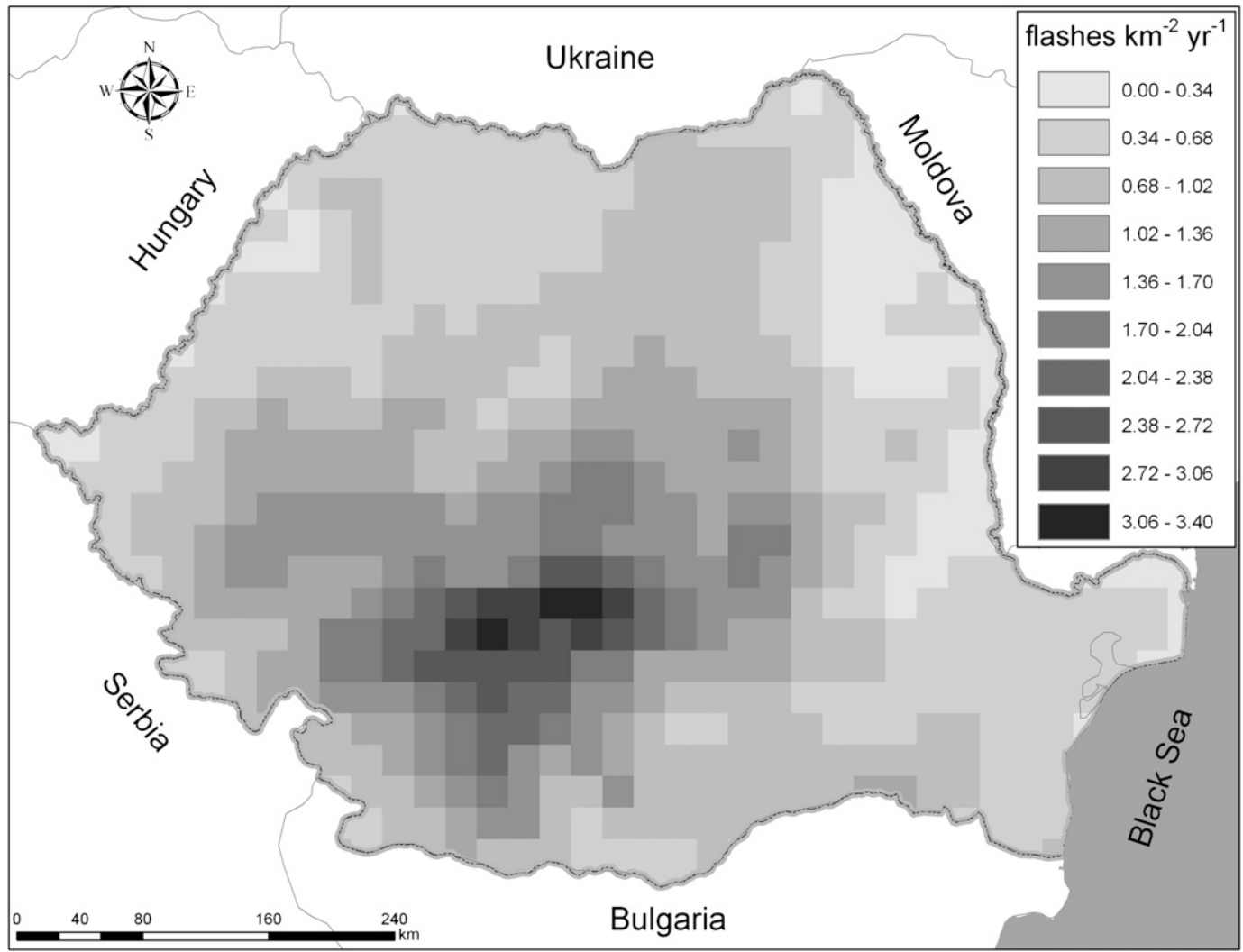

FIG. 4. Mean annual CG lightning density for Romania. Approximately 1.75 million flashes from 2003 to 2007 (except 2006) were analyzed to produce this map. No correction for detection efficiency has been applied.

a density value for each cell by counting the number of CG lightning flashes within the cell and dividing by the cell area. The density value (flashes $\mathrm{km}^{-2}$ ) is assigned to each cell.

\section{Results}

This section will begin with the general description of the characteristics of the mean CG lightning density between 2003 and 2007, except 2006 (section 3a). The next sections will summarize categories of monthly distribution (section 3b), positive CG lightning density (section 3c), percent of positive CG lightning (section 3d), mean peak current (3e) and diurnal variation of CG lightning (3f), and the CG lightning climatology in Romania.

\section{a. Total cloud-to-ground lightning density}

Tuomi and Mäkelä (2008) have shown on a 10-km grid that the average CG lightning density in Finland for the period 1998-2007 is 0.35 flashes $\mathrm{km}^{-2} \mathrm{yr}^{-1}$, with a maximum of 0.56 flashes $\mathrm{km}^{-2} \mathrm{yr}^{-1}$. Calculating the CG lightning density on a $20-\mathrm{km}$ grid, Schulz et al. (2005) have shown that the region with the highest CG lightning density in Austria has more than 6 flashes $\mathrm{km}^{-2} \mathrm{yr}^{-1}$, about $30 \%$ lower than the maximum-measured flash density of 9 flashes $\mathrm{km}^{-2} \mathrm{yr}^{-1}$ found by Orville and Huffines (2001) using the same grid in the United States for the Tampa-Orlando-Cape Canaveral, Florida, corridor. For Germany, the average CG lightning density is 2.8 flashes $\mathrm{km}^{-2} \mathrm{yr}^{-1}$ (Finke and Hauf 1996) and the highest values are more than 10 flashes $\mathrm{km}^{-2} \mathrm{yr}^{-1}$. A maximum value of 2.1 flashes $\mathrm{km}^{-2} \mathrm{yr}^{-1}$ was found by Rivas Soriano et al. (2005) for Spain, using CG lightning data from 1992 to 2001 and a 20-km grid. This maximum is related to the Pyrenees and Sistema Iberico mountain ranges.

Figure 3 shows the annual CG flash counts for total, negative, and positive ( $>10 \mathrm{kA}$ ) flashes. Because of the mesoscale and synoptic conditions for the development of deep moist convection, the annual flash count exhibits a year-to-year variability. The highest annual count (about 515000 flashes) was recorded in 2007. The annual variation of positive flashes shows a maximum $(2.3 \%)$ in 2003 and a minimum $(1.6 \%)$ in 2007.

Romania, despite its relatively small area $\left(238319 \mathrm{~km}^{2}\right)$, has an important variation in its terrain. The complex action of the advective and radiative factors, frontal or mesoscale processes, and topography and physical 


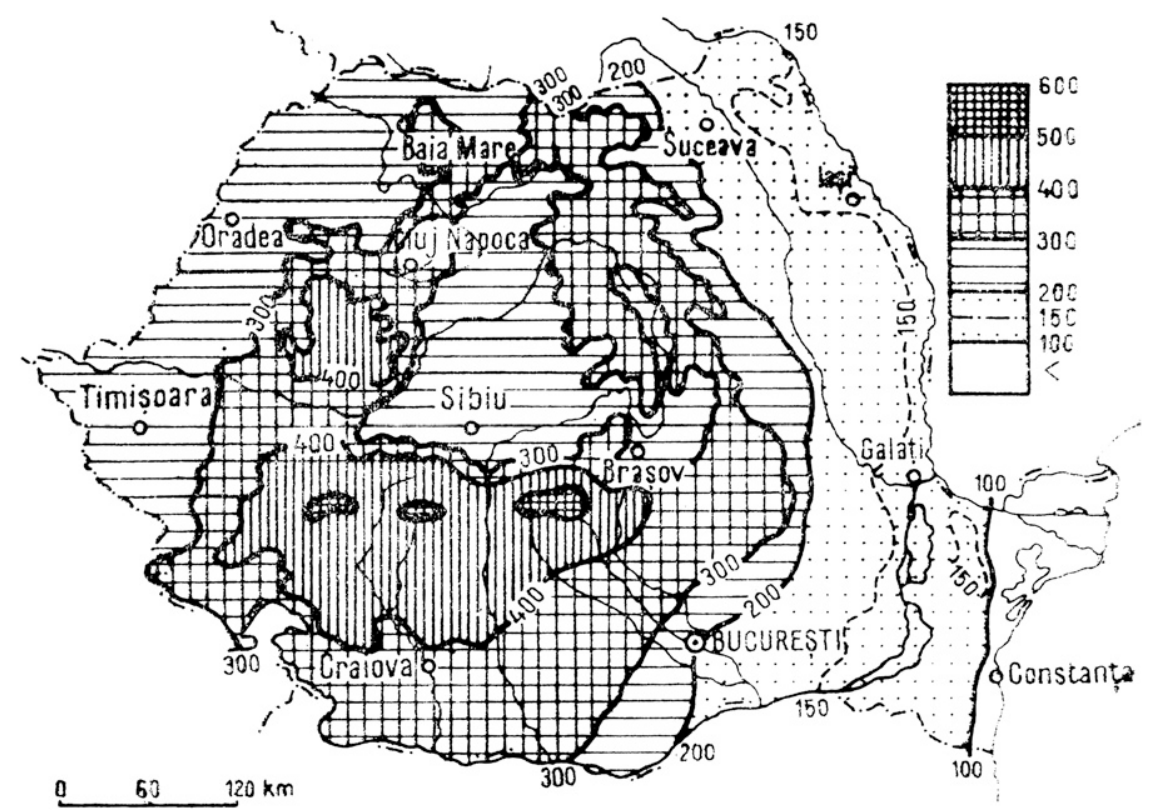

FIG. 5. Mean annual CG density for Romania, based on the data gathered by the CG lightning counters between 1966 and 1980. The scale represents the number of CG lightning strikes over $100 \mathrm{~km}^{2}$ (from Iliescu 1989).

geographical factors is uneven over Romania, inducing a large variety and modulation of the CG lightning activity over the country.

The mean annual CG lightning density is presented in Fig. 4 for contiguous Romania, and the values vary from less than 0.34 flashes $\mathrm{km}^{-2} \mathrm{yr}^{-1}$ in eastern and northwestern Romania to values greater than 2.38 flashes $\mathrm{km}^{-2} \mathrm{yr}^{-1}$ in southwestern and central Romania. Western Romania has westerly slopes, and the moist air embedded in the westerly flow interacts with these topographic features, increasing the lifetime of the thunderstorms. Toward the south, the moist air from the Mediterranean basin together with stronger insolation, resulting from the south-facing slopes, favors thunderstorm development.

The maximum value of CG lightning density, more than 3.06 flashes $\mathrm{km}^{-2} \mathrm{yr}^{-1}$, was recorded on the south slopes of the central meridional Carpathians. This agrees with the observation of Fosdick and Watson (1995) (for New Mexico) and López et al. (1997) (for Arizona) that the CG lightning density is sometimes greater over the slopes, leading to high-elevated terrain, and it has low values over large areas of rough terrain.

Over southeastern and eastern Romania, the low topography and drier air generate less intense thunderstorms. For the southern Romania plains, the highest density values are recorded in the western part (2.04 flashes $\mathrm{km}^{-2} \mathrm{yr}^{-1}$ ) and decrease toward the Black Sea $\left(<0.34\right.$ flashes $\left.\mathrm{km}^{-2} \mathrm{yr}^{-1}\right)$. In the northwestern Roma- nia plain, the values of CG lightning density are lower than 0.68 flashes $\mathrm{km}^{-2} \mathrm{yr}^{-1}$, and approximately the same values are observed on the eastern slopes of the Oriental Carpathians.

Iliescu (1989) has shown a similar pattern for the total CG lightning density, based on the data gathered by means of CG lightning counters between 1966 and 1980 (Fig. 5). The CG lightning counters network was composed of 100 counters with a detection range of $17.5 \mathrm{~km}$. The largest values observed by Iliescu (1989) were between 4 and 5 flashes $\mathrm{km}^{-2} \mathrm{yr}^{-1}$, observed over the meridional Carpathians (Fig. 5). The spatial pattern is similar with the one obtained from the RNLDN database (Fig. 4), but an overestimation of CG lightning density in Iliescu (1989) is observed because of the calibration of the CG counters, which results in detection of other sources of electromagnetic signals (Iliescu 1989).

Another possible cause for the distribution of CG lightning over Romania is the $\mathrm{S}$ shape of the Carpathian Mountains. A consequence of the interaction of this topography and westerly flow is the so-called Romanian Plain convergence zone (Stan-Sion and Antonescu 2006) that often forms in southern Romania. The S shape of the Carpathian Mountains deflects the flow of the general western circulation in two branches that converge in the southern Romanian plain. The convergence is also enhanced by the presence of two natural canyons on the Olt and Danube Rivers. Low-level warm and moist advection from the Mediterranean Sea provides good 


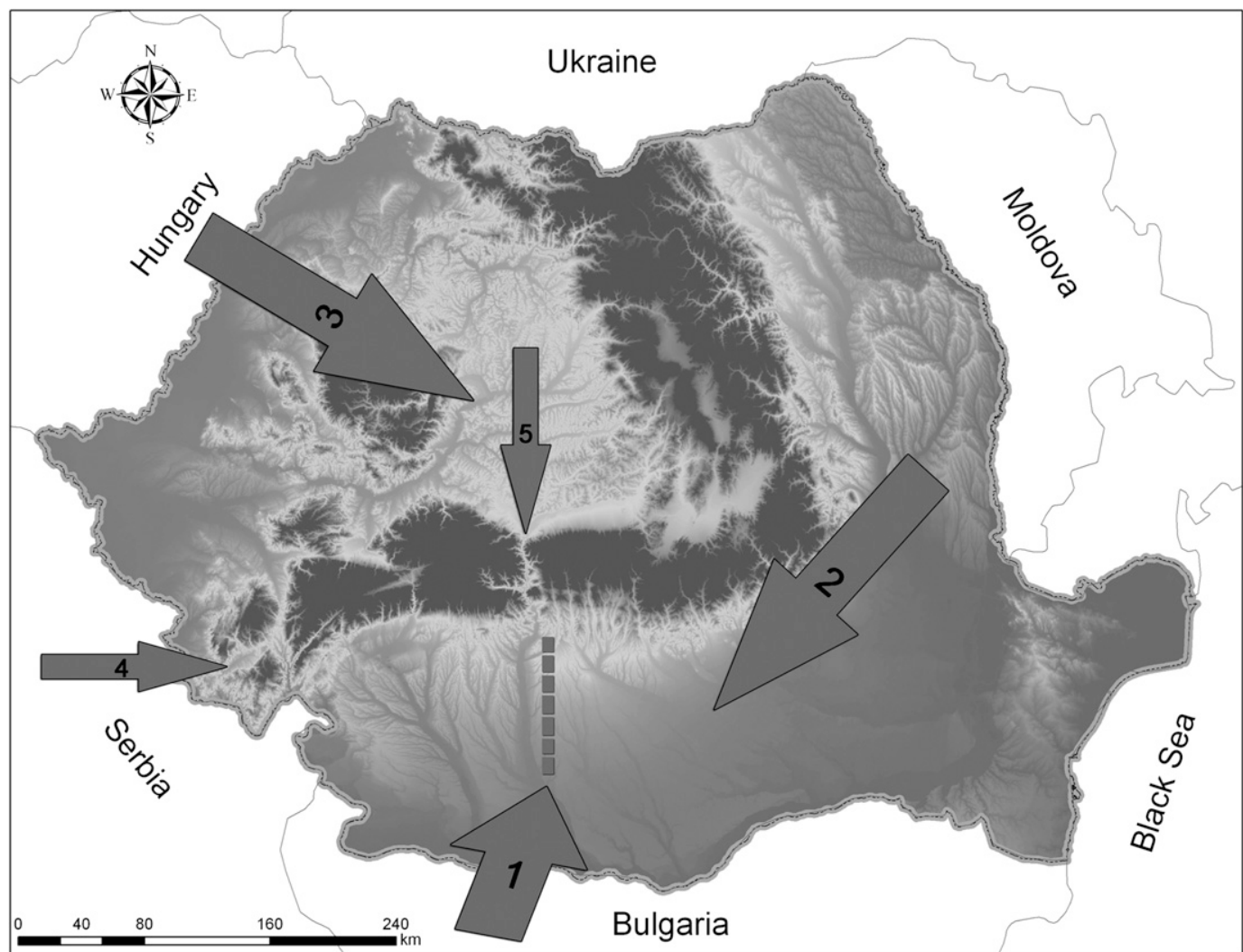

FIG. 6. The Romanian Plain convergence zone, with arrows depicting: 1) low-level moist advection from the Mediterranean Sea; 2) low-level flow around the Carpathian Mountains when a western high-pressure system approaches Romania; 3) upper-level flow; 4) the Danube Canyon; and 5) the Olt River canyon. The solid dashed line represents the region of convergence along the Olt River, where convection is often initiated.

conditions for storm initiations in the region of the convergence zone. If the northern flow prevails, then there are conditions for the development of a backbuilding convective line over the hills with southern slopes. The new cells formed toward the west, where the warm and moist air is lifted by the gust front, producing a backward propagation of the system (Fig. 6). This convergence zone is similar to other mesoscale convergence zones produced by flow around complex topography, such as the Puget Sound convergence zone (e.g., Mass and Dempsey 1985; Whitney et al. 1993; Chien and Mass 1997) and the Snake River convergence zone (e.g., Andretta and Hazen 1998; Steenburgh and Blazek 2001).

\section{b. Monthly distribution of total CG lightning}

Previous studies have shown that CG lightning flashes occur predominantly in the warm season (MaySeptember). Rivas Soriano et al. (2005) found that $84 \%$ of all CG flashes were counted between May and September, and that the maximum values occur in August and September. This maximum is due to the Mediterranean Sea, which supplies warm and humid air, thus increasing the convective activity, especially during the autumn when this effect is strongest. For the United States (Orville and Huffines 2001), the plot for mean monthly distribution of CG lightning is symmetrical in July. In Finland, the significant CG lightning activity starts in May, intensifies after mid-June, reaches its peak at mid-July, and fades out at the beginning of September (Tuomi and Mäkelä 2008). Schulz et al. (2005) have shown that the $96 \%$ of detected flashes in Austria occurred between May and September, with a peak in July.

For Romania, the monthly percentage of CG lightning is shown in Fig. 7. About $98 \%$ of all the CG lightning flashes were detected in May-September. The summer months (June-August) represent approximately $80 \%$ of the total number of CG lightning detected by the RNLDN between 2003 and 2007 (except 2006). The minimum values for flash counts are recorded in December $(0.022 \%)$ and January $(0.020 \%)$.

\section{c. Positive cloud-to-ground lightning density}

Positive CG flashes (Berger et al. 1975) are often associated with more severe damage to different objects 


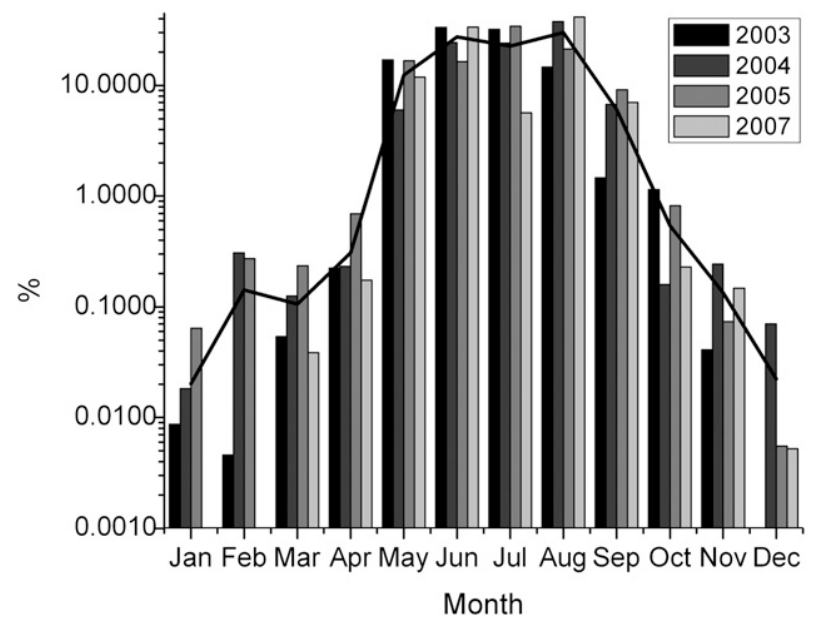

FIG. 7. Monthly variation of the CG lightning between 2003 and 2007, except 2006 and the mean monthly values (solid line). The monthly percentage of the annual total number of CG lightning for each year is represented on the ordinate.

than negative flashes (e.g., Nakahori et al. 1982; Idone et al. 1984) and are also more likely to start forest fires (e.g., Fuquay et al. 1967; Rakov and Uman 2003).

Figure 8 presents the mean annual positive CG lightning density for flashes with peak currents more than
$10 \mathrm{kA}$. For the period analyzed, the positive CG flashes represent $2.4 \%$ of the total CG lightning recorded. The highest values $\left(>0.04\right.$ flashes $\left.\mathrm{km}^{-2} \mathrm{yr}^{-1}\right)$ are observed in southwestern and central Romania, but the pattern is different than the total CG lightning density pattern (Fig. 4). High values ( $>0.02$ flashes $\mathrm{km}^{-2} \mathrm{yr}^{-1}$ ) are also observed in northern and western Romania.

For the United States, Orville and Huffines (2001) show the mean annual positive flash density has a maximum value ( 0.4 flashes $\mathrm{km}^{-2} \mathrm{yr}^{-1}$ ) in Florida and also in the vicinity of Houston, Texas, and the Texas-Louisiana border.

The positive flash counts for the United States (Orville and Huffines 2001) are at a maximum in June and July. The mean monthly variation of positive CG flashes from 2003 to 2007 is shown in Fig. 9. A broad peak occurs from May to August, with a maxima during May (25\%) and August (23\%). As in the case of the United States, (Orville and Huffines 2001) Fig. 9 suggests that the positive flashes' activity peaks earlier than the total activity (Fig. 7).

\section{d. Percent of positive cloud-to-ground lightning}

The mean annual percentage of positive CG flashes recorded by the RNLDN during the study period is

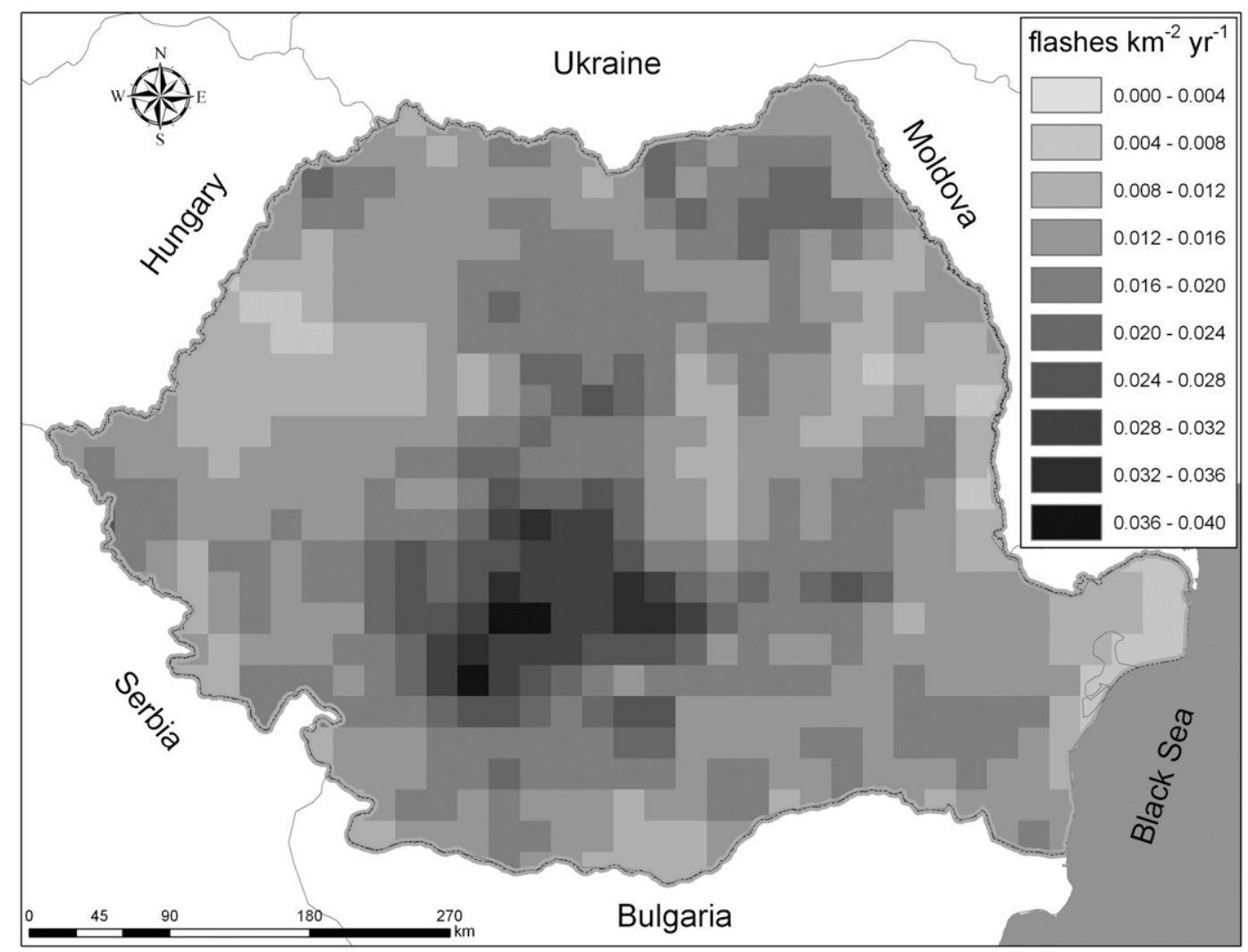

FIG. 8. Mean annual positive CG lightning density for Romania. 


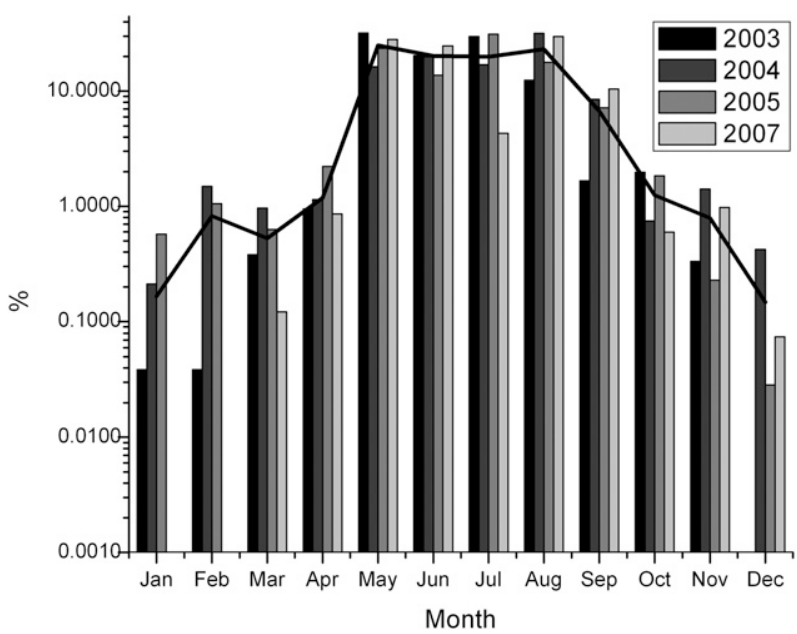

FIG. 9. As in Fig. 7, but for CG lightning.

plotted in Fig. 10. High values ( $>5.64 \%)$ are observed in the vicinity of the Romanian borders, except for the southern part. The reason for this finding could be attributable to the fact that positive CG flashes have a greater peak current than negative CG flashes, which results in a larger fraction of positive flashes being detected (Orville and Silver 1997) as distance increases from the perimeter of the lightning detection network. The lowest values $(<0.94 \%)$ occur over central Romania, the region with the highest values of total flash density.

For the Iberian Peninsula (Rivas Soriano et al. 2005), a large area shows values between $5 \%$ and $10 \%$. High percentages $(>20 \%)$ occur for the United States throughout the upper Midwest and along the West Coast and the lowest value occurs in Florida and over the Gulf Stream.

The mean monthly percentage of positive CG flashes varies from $15 \%$ to $19 \%$ in December and January to $1 \%$ to $3 \%$ in June, July, and August (Fig. 11). The increase in the percentage of positive flashes during the winter has been reported by other authors, (e.g., Clodman and Chisholm 1996; Orville and Silver 1997; Orville and Huffines 2001; Rivas Soriano et al. 2005), but as was stated by Orville and Huffines (2001), "the reason of the seasonal variation of the percentage of positive flashes is still a matter of conjecture." One possible reason for the winter maximum in positive flashes is the vertical wind shear. Brook et al. (1982) found a relationship between the wind shear, which would differentially separate the upper and lower negative charge regions, and the fraction of positive flashes produced in winter thunderstorms over Japan.

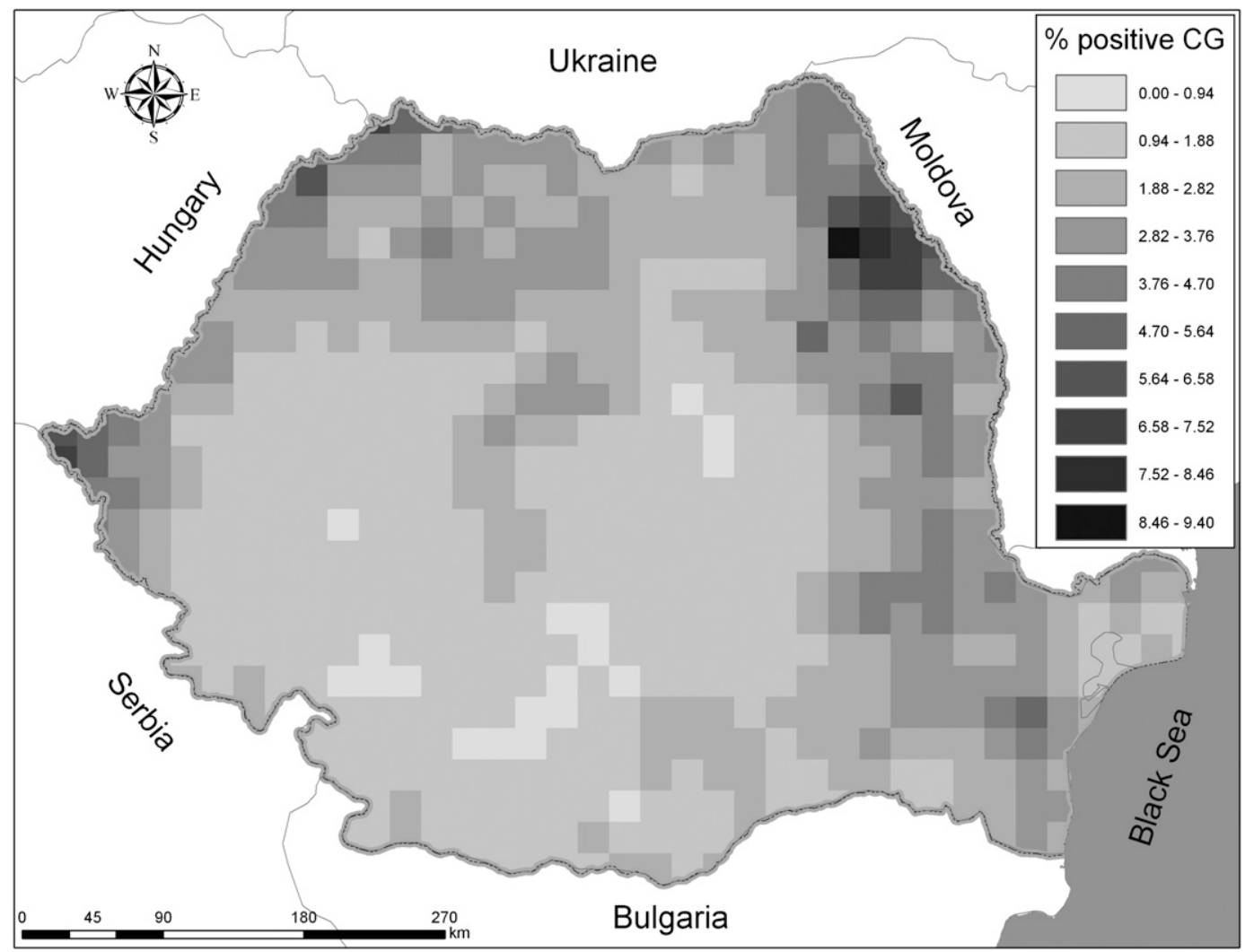

FIG. 10. Mean annual percentage of positive CG lightning. 


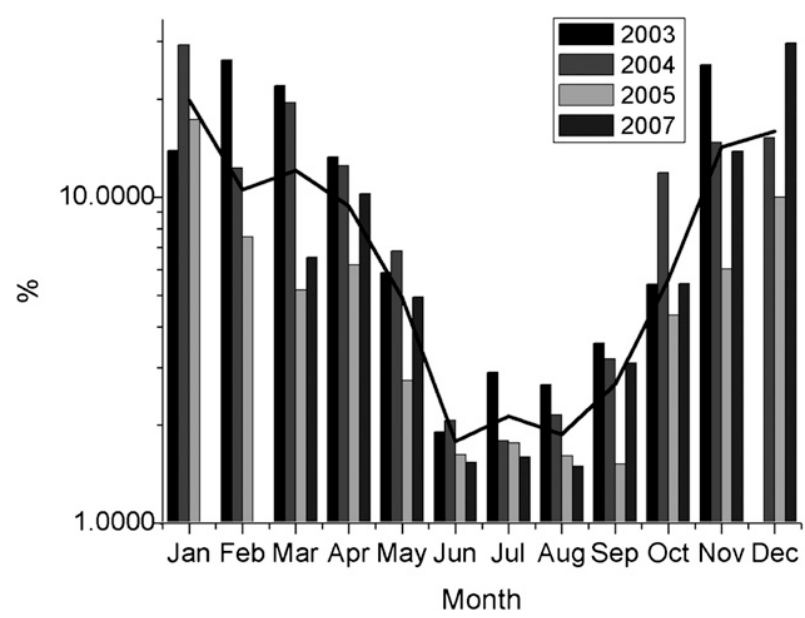

FIG. 11. Monthly variation of the percentage of positive CG between 2003 and 2007, except 2006, and the mean monthly values (solid line).

\section{e. Median peak currents}

The spatial distribution of the first-strike peak current for negative $(>8.5 \mathrm{kA})$ and positive ( $\geq 10 \mathrm{kA}$ ) flashes is represented in Fig. 12 and Fig. 13, respectively; each of these represent median values. For negative strikes, the high values range from to 25.0 to $42.5 \mathrm{kA}$ and are observed in western, northeastern, and southeastern Romania, close to the borders (Fig. 12). In the case of positive strikes, high values $(>63.6 \mathrm{kA})$, they follow the same spatial pattern as in the case of median peak currents for negative strikes (Fig. 13). Low values for median peak currents for both negative $(\leq 17 \mathrm{kA})$ and positive $(\leq 42.4 \mathrm{kA})$ strikes are observed in the central part of Romania. As was stated by Rivas Soriano et al. (2005), this effect can be attributed to the fact that the detection of weak flashes decreases with the increase of the distance to the nearest sensor. This effect is also detected in the geographical distribution of percent of positive flashes, with high values $(>5.64 \%)$ occurring close to the Romanian border, which corresponds to the edge of the coverage area of the RNLDN (Fig. 10).

In Fig. 14, the monthly distribution of median peak currents for both negative and positive first strikes is shown. The lowest value for negative and positive median peak currents occurs in July, with the maximum in January for negative currents and in March for positive currents. This variation from high values during the winter to low values in the summer was also observed by Brook (1992) and Orville and Huffines (2001) for the United States and Rivas Soriano et al. (2005) for the

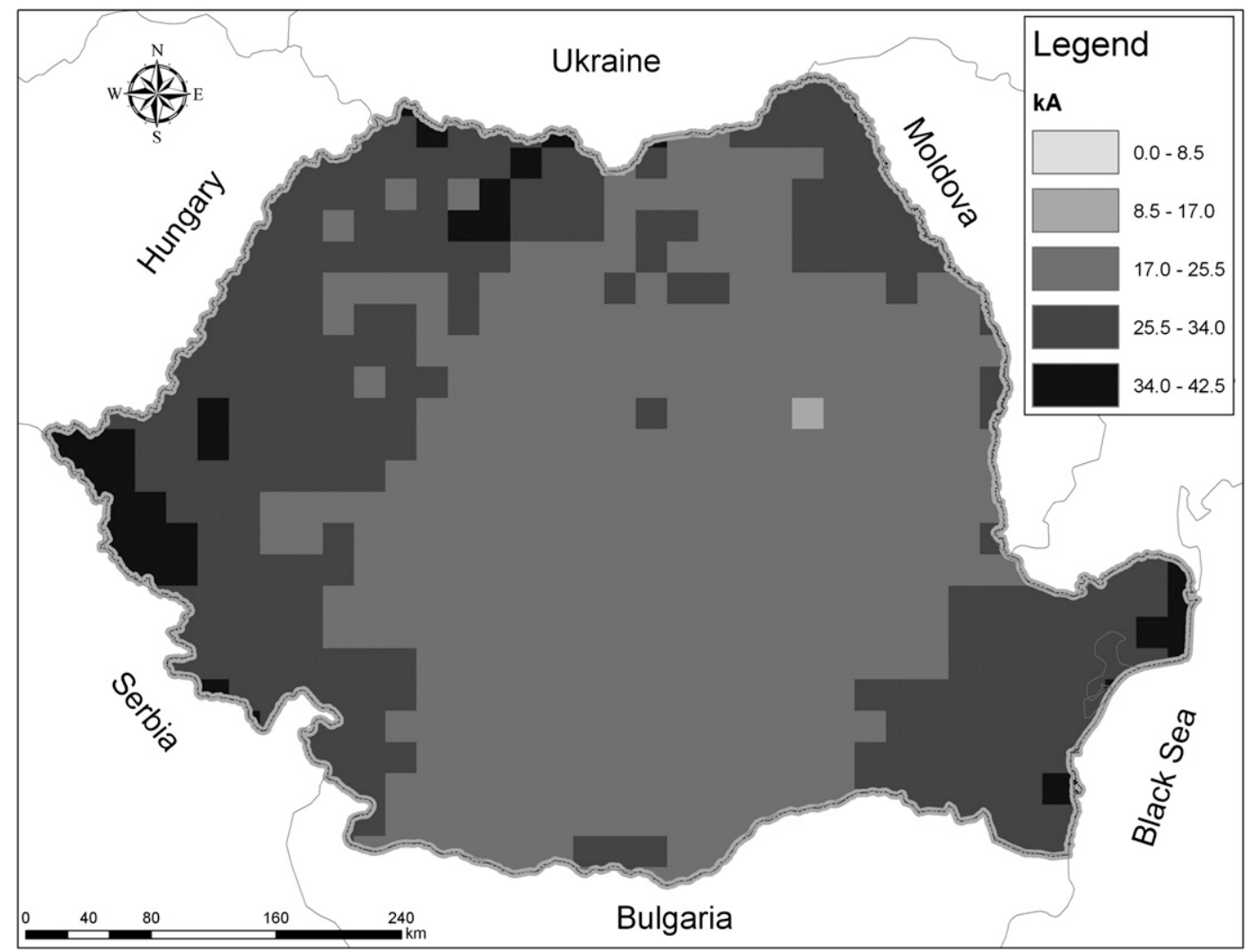

FIG. 12. First-strike negative median peak currents between 2003 and 2007, except 2006. 


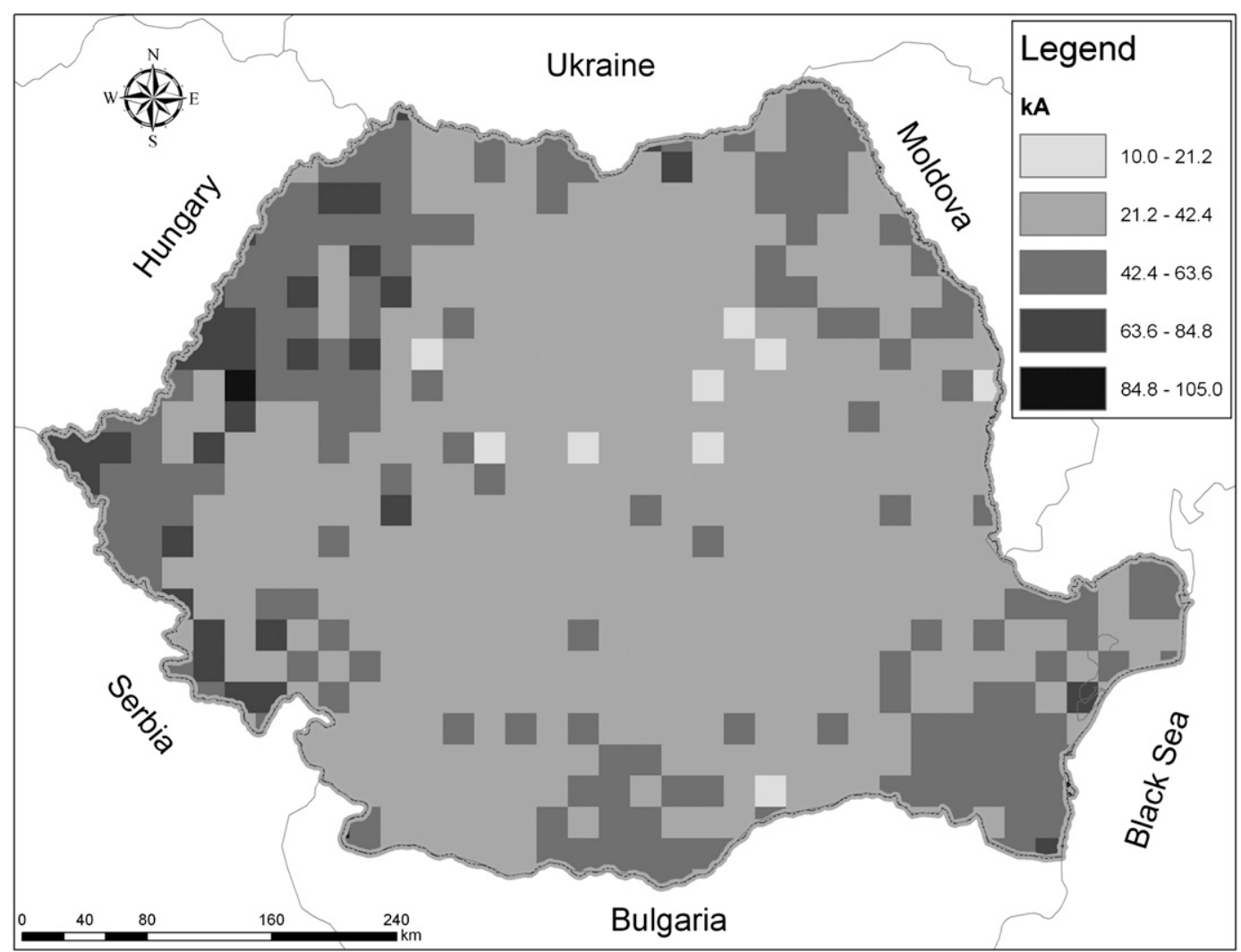

FIG. 13. As in Fig. 12, but for positive median peak currents.

Iberian Peninsula. Brook (1992) proposed an explanation for this variation, based on the observation that the electrical field-initiating lightning is greater during the winter than it is during the summer; therefore, winter discharges may be "more energetic than the summer" discharges and the peak currents are higher.

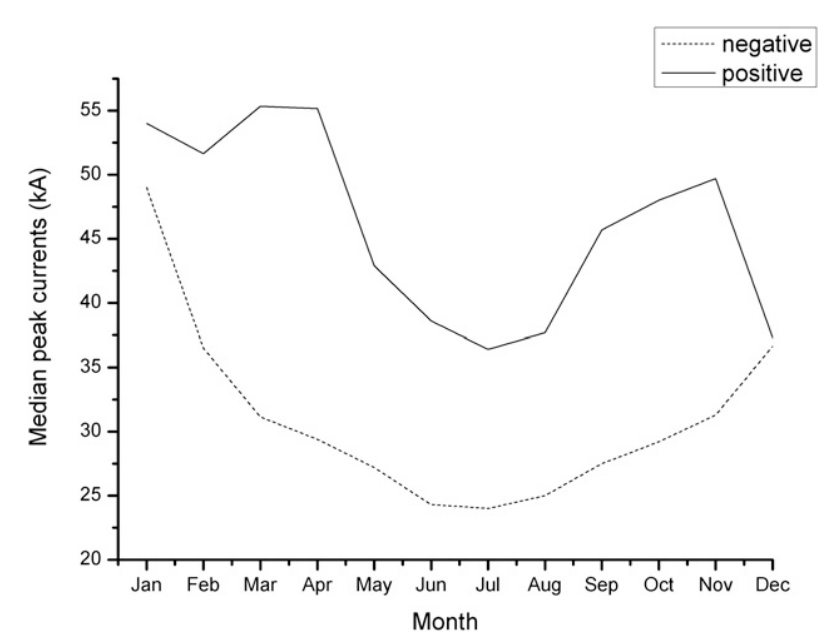

FIG. 14. Monthly variation of median peak current for negative and positive first strikes.

\section{f. Diurnal variation of total cloud-to-ground}

Figure 15 portrays the diurnal variation of the $\mathrm{CG}$ flashes with a resolution of $15 \mathrm{~min}$, as a percentage of the total number of CG flashes recorded during the study

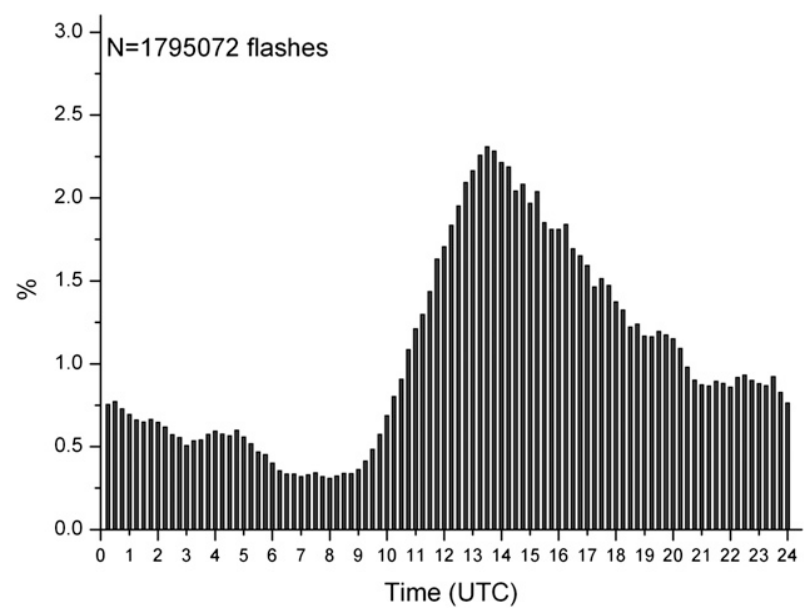

FIG. 15. Diurnal distribution of CG lightning from 2003 to 2007, except 2006, with a time resolution of $15 \mathrm{~min}$. The hourly percentage of the total number of CG lightning is represented on the ordinate. 

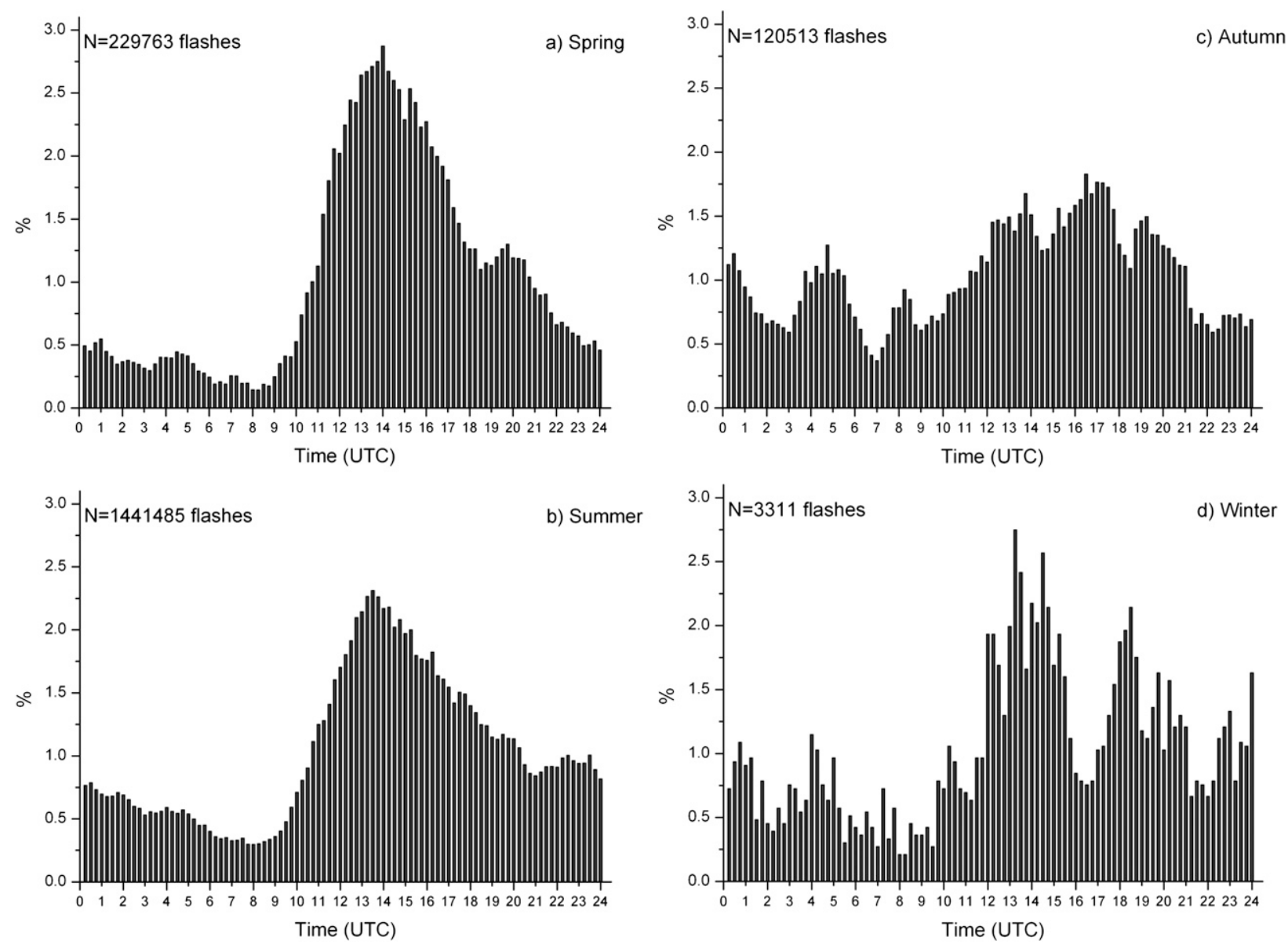

FIG. 16. As in Fig. 15, but for (a) spring, (b) summer, (c) autumn, and (d) winter.

interval. The largest number of CG flashes $(2.2 \%)$ occurred between 1230 and 1430 UTC (local time $=2 \mathrm{~h}+$ UTC) and the minimum between 0600 and 0800 UTC $(0.3 \%)$, with secondary maxima at $2130-0030$ and 0300 0500 UTC. A similar distribution centered in the afternoon was reported by Clodman and Chisholm (1996) for the southern Great Lakes region of the United States (Orville and Huffines 2001 for United States; Finke and Hauf 1996 for southern Germany; Areitio et al. 2001 for Basque Spain; Tuomi and Mäkelä 2008 for Finland).

In summer (Fig. 16a), the maximum of the CG lightning diurnal activity occurs at 1330 UTC and a secondary maximum at 2300 UTC. For spring (Fig. 16b), the diurnal maximum is also centered in the afternoon (1345 UTC), but the secondary peak occurs earlier (1945 UTC) than in the summer. The CG lightning diurnal cycle in summer and spring seems to be related to the diurnal cycle, with thunderstorms developing in the afternoon when solar heating is at maximum.

During autumn, the number of CG lightning flashes (Fig. 16c) decreases by approximately $90 \%$ when com- pared to summer. The CG flashes in autumn are mainly associated with cyclones that move from the Mediterranean Sea or from the North Atlantic toward the Black Sea (Iliescu 1989). Also, as was noted by Areitio et al. (2001), the CG lightning flashes' activity in early autumn is similar with that observed in summer. In winter (Fig. 16d), when solar heating is at minimum, the CG lightning flashes' maximum occurs in the afternoon, with greater variability because of the fewer number of flashes. Another cause of the variability in winter is frontal thunderstorms - the main lightning source in the absence of storms forced by heating - and fronts can pass at any time.

\section{Conclusions}

The present research focuses on the climatological characteristics of CG lightning in Romania. Approximately 1.75 million CG lightning flashes recorded by the RNLDN between 2003 and 2007 (except 2006) have been analyzed, including the geographical distribution, 
the monthly counts, and the diurnal variation for total and positive CG lightning flashes. The main conclusions are as follows:

1) The maximum annual CG lightning density $(>3.06$ strikes $\mathrm{km}^{-2} \mathrm{yr}^{-1}$ ) occurs in southwestern and central Romania. A possible explanation for this area of maximum annual strike density is the presence of the Romanian Plain convergence zone (Stan-Sion and Antonescu 2006) that is produced by the flow around the $\mathrm{S}$ shape of the Carpathian Mountains.

2) For the study period, the mean annual CG flash counts peak in the summer months of June-August, representing $80 \%$ of the total CG lightning activity.

3) The highest values for positive CG lightning density $\left(>0.028\right.$ strikes $\left.\mathrm{km}^{-2} \mathrm{yr}^{-1}\right)$ are observed in southwestern and central Romania. High values $(>0.012$ strikes $\mathrm{km}^{-2} \mathrm{yr}^{-1}$ ) are also observed in the northern part of the country.

4) The mean monthly positive flash counts have a broad maximum from May (25\%) to August (23\%).

5) The highest values for the percent of positive CG lightning flashes $(>5.64 \%)$ are observed in northeastern Romania. The lowest values $(<0.94 \%)$ occur over central Romania.

6) The mean monthly percentage of positive strikes peak have a range from a low of $1 \%$ to $3 \%$ in the summer months to a high of $19 \%$ in January.

7) The monthly variation of median peak currents has a maximum in winter and the minimum occurs in July, for both negative and positive currents.

8) The diurnal variation of CG lightning has a peak during 1230-1430 UTC. The maximum of the CG lightning diurnal activity occurs around 1345 UTC in spring and 1330 UTC in summer.

Further research is necessary, especially on the synoptic climatology of thunderstorms in Romania and on the climatological aspects of the Romanian Plain convergence zone.

Acknowledgments. We appreciate the assistance of Prof. David Schultz from the University of Helsinki and the Finnish Meteorological Institute for his helpful suggestions and advice on many aspects of this research and on improving the manuscript. We thank Dr. Aurora Bell and Alexandru Dumitrescu from the Romanian National Meteorological Administration and Prof. Sabina Stefan from the University of Bucharest for providing comments during the writing of this manuscript. We also want to give thanks to the anonymous reviewers for their comments, which helped to improve the manuscript.

\section{REFERENCES}

Andretta, T. A., and D. S. Hazen, 1998: Doppler radar analysis of a Snake River Plain convergence event. Wea. Forecasting, 13, 482-491.

Areitio, J., A. Ezcurra, and I. Herrero, 2001: Cloud-to-ground lightning characteristics in the Spanish Basque Country area during the period 1992-1996. J. Atmos. Sol. Terr. Phys., 63, 1005-1015, doi:10.1016/S1364-6826(01)00013-X.

Berger, K., R. B. Anderson, and H. Kroninger, 1975: Parameters of lightning flashes. Electra, 80, 23-37.

Biron, D., 2009: LAMPINET-lightning detection in Italy. Lightning: Principles, Instruments and Applications: Review of Modern Lightning Research, H. D. Betz, U. Schumann, and P. Laroche, Eds., Springer, 141-159.

Brook, M., 1992: Breakdown of electric fields in winter storms. Res. Lett. Atmos. Electr., 12, 47-52.

—_, M. Nakano, P. Krehbiel, and T. Takeuti, 1982: The electrical structure of the Hokuriku winter thunderstorms. J. Geophys. Res., 87, 1207-1215.

Chien, F. C., and C. F. Mass, 1997: Interaction of a warm-season frontal system with the coastal mountains of the western United States. Part II: Evolution of a Puget Sound convergence zone. Mon. Wea. Rev., 125, 1730-1752.

Clodman, S., and W. Chisholm, 1996: Lightning flash climatology in the southern Great Lakes region. Atmos.-Ocean, 32, 345-377.

Cummins, K. L., M. J. Murphy, E. A. Bardo, W. L. Hiscox, R. B. Pyle, and A. E. Pifer, 1998: A combined TOA/MDF technology upgrade of the U.S. National Lightning Detection Network. J. Geophys. Res., 103 (D8), 9035-9044.

Curran, E. B., R. L. Holle, and R. E. López, 2000: Lightning casualties and damages in the United States from 1959 to 1994. J. Climate, 13, 3448-3464.

Finke, U., and T. Hauf, 1996: The characteristics of lightning occurrence in Southern Germany. Contrib. Atmos. Phys., 69, 361-374.

Fosdick, E. K., and A. I. Watson, 1995: Cloud-to-ground lightning patterns in New Mexico during the summer. Nat. Wea. Dig., 19, $17-24$.

Fuquay, D. M., R. G. Baughman, A. R. Taylor, and R. G. Hawe, 1967: Characteristics of seven lightning discharges that caused forest fires. J. Geophys. Res., 72, 6372-6373.

Holle, R. L., R. E. López, and C. Zimmermann, 1999: Updated recommendations for lightning safety-1998. Bull. Amer. Meteor. Soc., 80, 2035-2041.

Idone, V. P., R. E. Orville, and R. W. Henderson, 1984: Ground truth: A positive cloud-to-ground lightning flash. J. Climate Appl. Meteor., 23, 1148-1151.

Iliescu, M. C., 1989: Atmospheric Electrical Activity over Romania (in Romanian). Editura Academiei Republicii Socialiste România, 144 pp.

Ioana, M., V. Ivanovici, E. Cordoneanu, D. Banciu, A. Apostu, and B. Ford, 2004: SIMIN-The integrated system for meteorological surveillance, forecast and alert in Romania. Preprints, 20th Int. Conf. on IIPS for Meteorology, Oceanography, and Hydrology, Seattle, WA, Amer. Meteor. Soc., 11.2. [Available online at http://ams.confex.com/ams/84Annual/techprogram/ paper_70954.htm.]

López, R. E., R. L. Holle, A. I. Watson, and J. Skindlov, 1997: Spatial and temporal distributions of lightning over Arizona from a power utility perspective. J. Appl. Meteor., 36, 825-831.

Mass, C. F., and D. P. Dempsey, 1985: A topographically forced convergence line in the lee of the Olympic Mountains. Mon. Wea. Rev., 113, 659-663. 
Nakahori, K., T. Egawa, and H. Mitani, 1982: Characteristics of winter lightning currents in Hokuriku district. IEEE Trans. Power Appar. Syst., 101, 4407-4412.

Orville, R. E., and A. C. Silver, 1997: Lightning ground stroke density in the contiguous United States: 1992-95. Mon. Wea. Rev., 125, 631-638.

— , and G. R. Huffines, 2001: Cloud-to-ground lightning in the United States: NLDN results in the first decade, 1989-98. Mon. Wea. Rev., 129, 1179-1193.

Rakov, V. A., and M. A. Uman, 2003: Lightning: Physics and Effects. Cambridge University Press, 687 pp.

Reap, R. M., and R. E. Orville, 1990: The relationships between network lightning surface and hourly observations of thunderstorms. Mon. Wea. Rev., 118, 94-108.

Rivas Soriano, L., F. De Pablo, and T. Clemente, 2005: Ten-year study of cloud-to-ground lightning activity in the Iberian Peninsula. J. Atmos. Sol. Terr. Phys., 67, 1632-1639, doi:10.1016/ j.jastp.2005.08.019.

Schulz, W., K. Cummins, G. Diendorfer, and M. Dorninger, 2005: Cloud-to-ground lightning in Austria: A 10-year study using data from a lightning location system. J. Geophys. Res., 110, D09101, doi:10.1029/2004JD005332.

Stan-Sion, A., and B. Antonescu, 2006: Mesocyclones in RomaniaCharacteristics and environments. Preprints, 23rd Conf. on Severe Local Storms, St. Louis, MO, Amer. Meteor. Soc., 9.4.
[Available online at http://ams.confex.com/ams/pdfpapers/ 115304.pdf.]

Steenburgh, W. J., and T. R. Blazek, 2001: Topographic distortion of a cold front over the Snake River Plain and central Idaho Mountains. Wea. Forecasting, 16, 301-314.

Tuomi, T. J., and A. Mäkelä, 2008: Thunderstorm climate of Finland 1998-2007. Geophysica, 44 (1-2), 67-80.

Wacker, R. S., and R. E. Orville, 1999a: Changes in measured lightning flash count and return stroke peak current after the 1994 U.S. National Lightning Detection Network upgrade. 1. Observations. J. Geophys. Res., 104, 2151-2157.

— and _ 1999b: Changes in measured lightning flash count and return stroke peak current after the 1994 U. S. National Lightning Detection Network upgrade. II. Theory. J. Geophys. Res., 104, 2159-2162.

Whitney, W. M., R. L. Doherty, and B. R. Colman, 1993: A methodology for predicting the Puget Sound convergence zone and its associated weather. Wea. Forecasting, 8, 214-222.

Wierzchowski, J., M. Heathcott, and M. D. Flannigan, 2002: Lightning and lightning fire, central cordillera, Canada. Int. J. Wildland Fire, 11, 41-51.

Zajac, B. A., and S. A. Rutledge, 2001: Cloud-to-ground lightning activity in the contiguous United States from 1995 to 1999. Mon. Wea. Rev., 129, 999-1019. 